\title{
Students' Approaches to Learning (SAL) in a Curriculum Problem-Based Learning and Non-Problem-Based Learning
}

\author{
Edi Purwanto* and Indah Dwi Pratiwi \\ Department of Nursing, Faculty of Health Science, University of Muhammadiyah Malang, Indonesia \\ Jalan. Bendungan Sutami 188A, Kota Malang, Jawa Timur, 65145 \\ *Corresponding author: purwa_edi@umm.ac.id
}

\begin{abstract}
Background: Problem-based learning is learning where the results of the work process to understand and solve a problem. Study on approach to learning student / students' approaches to learning (SAL) and problem-based learning (PBL) has been observed internationally. However, there is no published research on the differences students' approaches to learning curriculum anatar PBL and non-PBL in Indonesia. Therefore, it is important to know the nursing students 'approach to learning / students' approaches to learning $(S A L)$ within the context of problem based learning $(P B L)$ and Non-Problembased learning (Non-PBL). Objective: The purpose of this research is 1). To describe the sociodemographic characteristics (sex, age, and origin) of nursing students; 2). To identify approach to learning of nursing students in PBL and non-PBL curriculum; 3). To compare the approach to student learning (students' approaches to learning) between PBL and non-PBL curriculum. Method: This research used a quantitative research. Result: Majority of respondents were female, 18 years old, came from Java and adopted a deep approach to learning both in PBL and Non-PBL groups. Different test results that do not found any significant difference in students' approach to learning in PBL groups and Non-PBL. Conclusion: student who adopted a deep approach tend to have a better understanding in the subject compared to those who adapted surface approach to learning.
\end{abstract}

Keywords: Approach to Learning, Nursing, Student, Problem-Based Learning, Curriculum, NonProblem Based Learning

\section{INTRODUCTION}

Problem based learning is learning which results from the work process in understanding and solving a problem (Barrows 1980 in Barret 2005). The first problem-based learning (PBL) was conducted in 1969 by the Faculty of Medicine, Faculty of Health Sciences, McMaster University, Canada (Gwee 2008). The McMaster University of Canada has integrated multidisciplinary education and lifelong learning in professional practice. The university is seen by many as a pioneer of Problem-Based Learning (PBL) (Metcalfe 2013). Since 1992, McMaster University's School of Nursing has been internationally recognized as the World Health Organization (WHO) Collaborating Center for Nursing Development (Metcalfe 2013).

According to Gwee (2008), the PBL method is considered an innovative and alternative pathway that encourages active peer learning and teaching with an open communication style. PBL developed throughout the world (including Southeast Asia). In the late 1990s, universities in Singapore, Taiwan, Malaysia and the Philippines introduced a problem-based learning curriculum (O'Grady et al., 2012). Meanwhile, in Indonesia, the Faculty of Medicine of the International Program, University of Gadjah Mada (UGM) conducted the first problem-based 
learning in 2002 (HPEQ 2013). Six years later, the Ministry of National Education, in Indonesia has introduced a problem-based learning approach to higher education in the faculties of medicine, health sciences and nursing (Sub Directorate of PPP 2008).

The study of student approaches to learning (SAL) and problem-based learning (PBL) has been studied internationally (Gijbels et al. 2009; Choy, O'Grady \& Rotgans 2012). The research of SAL and PBL in Indonesia was conducted by Purwanto (2014) on the nursing students' approaches to learning in a problem-based learning (PBL) curriculum in Indonesia. The results showed that the majority of respondents with PBL curriculum adopted Deep Approaches to Learning $(n=204,82.3 \%)$. However, no published studies have been made of the differences in students' approaches to learning between PBL and Non-PBL curricula in Indonesia. Therefore, it is important to know the approach of nursing students to learn / students' approaches to learning (SAL) in the context of problem based learning (PBL) and Non-Problem based learning (Non-PBL).

\section{METHOD}

This research used a quantitative research. In this study, we compare students' approaches to learning on PBL and Non-PBL curricula. This study was conducted at Undergradute Nursing Program (S1) in Faculty of Health Sciences, University of Muhamamdiyah Malang, Indonesia. They has implemented a problem-based learning program (PBL) since 2011. Population in this research was all student of Diploma and Undergraduate Nursing Program which involved 900 students. The respondents involved in this research were 248 students, comprised of 124 respondents from Undergraduate Nursing Program (PBL group) and 124 respondents from Diploma Nursing Program (Non-PBL group).

The respondents were asked to fill out a self-administered questionnaire (SAQ) which consisted of two parts, namely: part one includes data on the three socio-demographic characteristics of respondents: gender, age, and origin; part two is a modified Problem-Based Learning Revised Two-Factor Study Process Questionnaire (PBL-R-SPQ) by Dolmans, Wolfhagen and Ginns (2010). Respondents' answers to each of the 18 PBL-SPQ questions assessed on a 5-point Likert scale (5 = always or nearly always, $4=$ often, $3=$ half time, $2=$ sometimes, and $1=$ never or rarely) Biggs, Kember \& Leung 2001; Dolmans, Wolfhagen \& Ginns 2010). For the second instrument using Study Process Questionnaire (SPQ) (Biggs, Kember \& Leung 2001). Instruments in this study have been tested for the validity and reliability. Reliability test result in this research was 0,73 (instrument PBL-SPQ) and 0,85 (SPQ instrument).

The data was analyzed using Social SPSS Version Package 22 (SPSS). Assessing the normality of data is done to test the distribution of scores on the dependent variable. As shown by Plichta and Garzon (2009) and Sedgwick (2012), the type of distribution (ie, normal or other) determines which statistics can be used to analyze the data. In this study, the normality test results from the data obtained results that the distribution of data is not normally distributed. Therefore, non-parametric statistical analysis is used to check data (Pallant 2011). Descriptive analysis is used to describe the socio-demographics of students. The three sociodemographic characteristics of the respondents are as follows: gender, age, and regional origin. Inferential analysis is presented to compare students' approaches to learning (SAL) in PBL and Non-PBL groups using Mann-Whitney U Test. 


\section{RESULT AND DISCUSSION}

The distribution of respondents in the PBL and Non-PBL groups was compared according to socio-demographic characteristics that included gender, age and regional origin. Presentation of data will be done in sequence.

Table 1 Frequency distribution of respondents based on gender

\begin{tabular}{lllll}
\hline Gender & PBL & \multicolumn{3}{c}{ Non-PBL } \\
\cline { 2 - 5 } & $\mathrm{n}$ & $\%$ & $\mathrm{n}$ & $\%$ \\
\hline Male & 53 & 42.7 & 50 & 40.3 \\
Female & 71 & 57.3 & 74 & 59.7 \\
Total & 124 & 100 & 124 & 100 \\
\hline
\end{tabular}

In the two groups of respondents, gender distribution was dominated by women, both in the PBL group $(n=71,57.3 \%)$ and non-PBL group $(n=74,59.7 \%)($ Table 1$)$. The majority of respondents were women, which may be due to the fact that the sample consists mostly of nursing students both from the PBL group (Undergraduate Nursing Program) and the non-PBL group (Diploma Nursing Program) which is mostly women. The gender equilibrium in this study is supported by several previous studies which reported that more than half of the respondents were women (Groves 2005; Tiwari et al. 2006; Kek, Darmawan \& Chen 2007; Abraham et al 2008; Papinczak, Young \& Groves 2008; Dolmans, Wolfhagen, \& Ginns 2010; Chen et al 2011; Choy, O'Grady \& Rotgans 2012; Emilia, Bloomfield \& Rotem 2012; Gurpinar et al. 2013; Sabzevari, Abbaszade \& Borhani 2013; Salamonson et al. 2013). Their statistical results on gender showed that gender representation in the sample reflects a wider population of students in the field of nursing.

Based on their age, respondents in both PBL and Non-PBL groups were at least 18 years of age. However, the two groups had different statistical values, the PBL group (maximum age $=23$ years, mean $=18.85$ years, $\mathrm{SD}= \pm 1.08$ ) and the non-PBL group (maximum age $=22$ years, mean $=19.73$ years, $\mathrm{SD}= \pm 0.79)($ Table 2$)$.

Table 2 Frequency distribution of respondents based on age

\begin{tabular}{lll}
\hline Age & PBL & Non-PBL \\
\hline Minimum & 18 & 18 \\
Maximum & 23 & 22 \\
Mean & 18.85 & 19.73 \\
SD & 1.08 & 0.79 \\
\hline
\end{tabular}

Referring to the age of the respondents, the majority of respondents were 20 years and younger with an average age of 21 years. This finding is consistent with previous research by Brady (2005), Tiwari et al. (2006) and Chen et al. (2011) who also found the same average age of 20 years.

Table 3 Frequency distribution of respondents based on origin

\begin{tabular}{lllll}
\hline Origin & \multicolumn{2}{c}{ PBL } & \multicolumn{2}{c}{ Non-PBL } \\
\cline { 2 - 5 } & $\mathrm{n}$ & $\%$ & $\mathrm{n}$ & $\%$ \\
\hline Java & 65 & 52.4 & 73 & 58.9 \\
Non Java & 59 & 47.6 & 51 & 41.1 \\
Total & 124 & 100 & 124 & 100 \\
\hline
\end{tabular}

Distribution of respondents based on their local origin indicates that more than half of respondents came from Java Island (PBL, $\mathrm{n}=65,52.4 \%$ and Non-PBL, $\mathrm{n}=73,58.9 \%$ ) (Table $3)$. 
Tabel 4 Frequency distribution of respondents based on their approach to learning

\begin{tabular}{lcccc}
\hline Students' approaches to learning & \multicolumn{2}{c}{ PBL } & \multicolumn{2}{c}{ Non-PBL } \\
\cline { 2 - 5 } & $\mathrm{n}$ & $\%$ & $\mathrm{n}$ & $\%$ \\
\hline Deep approach to learning & 107 & 86.3 & 97 & 78.2 \\
Surface approach to learning & 17 & 13.7 & 27 & 21.8 \\
Total & 124 & 100 & 124 & 100 \\
\hline
\end{tabular}

Table 4 shows that the majority of respondents in the two groups adopted a deep approach to learning (PBL, $\mathrm{n}=107,86.3 \%$ and non-PBL, $\mathrm{n}=97,78.2 \%$ ).

The result of the distribution of the frequency shows that most respondents adopted deep approach to learning more than surface approach to learning both in PBL and Non-PBL learning. Students tended to learn more comprehensively in a PBL tutorial environment. According to Groves (2005), students develop a deep approach to learning to learn and improve individuals learn their self-efficacy during problem-based learning (PBL). This finding is similar to previous studies that reported that students tend to adopt a deep approach to learning rather than surface approach to learning (Groves, 2005; Dolmans, Wolfhagen, \& Ginns, 2010; Gurpinar et al., 2013). Students with higher scores in deep approach to learning have higher internal motivation and intention to use deep approach to learning (Sabzevari, Abbaszade \& Borhani 2013). Sabzevari, Abbaszade \& Borhani (2013) have suggested in other studies that students who adopt deep approach to learning in the learning process deliver better results than students who adopt surface approach to learning (Papinczak, Young \& Groves 2008). A deep learner is able to acquire skills in certain cases of problem solving, apply their own knowledge, and acquire new information while solving this problem with their clinical reasoning skills (Sadlo \& Richardson, 2003; Papinczak, Young \& Groves, 2008). This is similar to a study by Metcalfe (2013), which has suggested that students can relate concepts and understand them in a clinical setting, typical of deep learner traits.

The findings in this study also showed that problem-based learning strategies will encourage more students to apply deep approach to learning in their learning. Students who do so try to investigate the relationship between and integration of different parts of the lessons and their tasks. The findings of this study are congruent with the study of Abraham et al. (2008), which states that scores of students who adopt deep approach to learning and strategic approaches to learning are significantly higher than non-PBL students. This finding is consistent with Mattick, Dennis and Bligh (2004) research, which shows that students achieve higher scores on the deep approach to learning from surface approach to learning. This study also revealed a significant relationship between learner deep approach to learning with higher academic scores (Mattick et al., 2004).

The respondents' learning approaches to PBL and Non-PBL groups were further analyzed by using the Mann-Whitney U Test comparing its mean values.

Tabel 5 Mean rank's difference of SAL PBL and SALNon-PBL

\begin{tabular}{llll}
\hline \multicolumn{2}{l}{ Grouping } & N & Mean Rank \\
\hline \multirow{3}{*}{ SAL } & Non-PBL & 124 & 119.50 \\
& PBL & 124 & 129.50 \\
& Total & 248 & \\
\hline
\end{tabular}

Table 5 showed that the mean score of SAL scores in the PBL group (129.5) is higher than the non-PBL group (119.5). The results showed that respondents in PBL group had better performance in terms of deep approach to learning compared to respondents in the Non-PBL group. The findings in this study also showed that problem-based learning strategies will encourage students to apply more deep approach to learning in their learning. Students who do so, try to investigate the relationship between and integration of different parts of the lessons and their tasks. The findings of this study are congruent with the study of Abraham et al. (2008), 
which states that scores of students who adopt deep approach to learning in PBL approaches and strategic approaches to learning are significantly higher than non-PBL students.

\begin{tabular}{l|l}
\multicolumn{2}{l}{ Table 6 Mann-Whitney U Test Results } \\
\hline & SAL \\
\hline Mann-Whitney U & 7068.000 \\
Wilcoxon W & 14818.000 \\
Z & -1.659 \\
Asymp. Sig. (2-tailed) & .097 \\
a. Grouping Variable: PBL dan Non-PBL \\
\hline
\end{tabular}

Mann-Whitney U Test results showed that there was no statistically significant difference in students' approach to learning in PBL and non-PBL groups ( $\mathrm{p}$-value $=0.097$ ) (Table 5). The results of this study are not the same as those obtained by Abraham et al. (2008) found that students 'approach to learning in students with PBL approach differed significantly from students' approach to learning in students with non-PBL approach.

\section{CONCLUSION}

The results of this study showed that the majority of respondents are women, aged 18 years, came from the island of Java and adopted a deep approach to learning both in the group PBL and Non-PBL. Different test results were not found that there were significant differences in students' approach to learning in PBL and Non-PBL groups. There are a number of recommendations that can be made. First, further research should be designed to include other variables, such as academic achievement, critical thinking skills or learning outcomes with reference to a student's approach to learning. Second, further research should explore students' perceptions of assessment in the context of PBL and whether this influences their learning approach. Student perceptions may be considered by the curriculum development team to improve the PBL process in the future. Indonesian nursing educators may need to respond by adopting a more rigorous approach and practice in higher education, especially in the context of teaching and learning.

\section{REFERENCES}

Abraham, RR, Vinod, P, Kamath, MG, Asha, K \& Ramnarayan, K (2008). Learning approaches of undergraduate medical students to physiology in a non-PBL and PBL oriented curriculum. Advances in Physiology Education, 32, 35-37.

Biggs, J, Kember, D, \& Leung D.Y.P. (2001). The revised two-factor study process questionnaire: R-SPQ-2F, British Journal of Educational Psychology, 71, 133-149.

Brady, M.M.A (2005). The effect of a metacognitive intervention on approach to and selfregulation of learning in baccalaureate nursing students. Journal of Nursing Education, 44(7), 297-304.

Chen, S.L., Liang, T., Lee, Mi, \& Liao, I.C. (2011). Effects of concept map teaching on students' critical thinking and approach to learning and studying. Journal of Nursing Education, 50(8), 466-469.

Choy, J.L.F., O'Grady, G., \& Rotgans, J.I. (2012). Is the study process questionnaire (SPQ) a good predictor of academic achievement? Examining the mediating role of achievementrelated classroom behaviour. Instructional Science, 40, 159-172.

Dolmans, D.H.J.M., Wolfhagen, I.H.A.P., Ginns, P. (2010). Measuring approaches to learning in a problem based learning context. International Journal of Medical Education, 1, 5560 . 
Gijbels, D., Coertjens, L., Vanthournout, G., Struyf, E. \& Petegem, P.V. (2009). Changing students' approaches to learning a two-year study within a university teacher training course. Educational Studies, 35(5), 503-523.

Groves, M. (2005). Problem-based learning and learning approach: is there a relationship?. Advances in Health Sciences Education, 10, 315-326.

Gurpinar, E., Kulac, E., Tetik, C., Akdogan, I. \& Mamakli, S. (2013), 'Do learning approaches of medical students affect their satisfaction with problem-based learning?', Advances in Physiology Education, 37, 85-88.

Health Professional Education Quality (HPEQ). (2013). Kurikulum Kedokteran Berdasar Kompetensi. Retrieved

from http://hpeq.dikti.go.id/v2/index.php?option=com_content\&view=article\&id=91:kurikul um-kedokteran-berdasar-kompetensi\&catid=16:berita-terkait\&Itemid=197.

Mattick, K., Dennis, I., \& Bligh, J. (2004). Approaches to learning and studying in medical students- validation of a revised inventory and its relation to student characteristics and performance. Medical Education, 38, 535-543.

O’Grady, G., Yew, E.H.J., Goh, K.P.L., \& Schmidt, H.G. (2012). One day one problem. Singapore: Springer Science Business Media.

Papinczak, T., Young, L., Groves, M. (2008). Effects of a meta-cognitive intervention on students' approaches to learning and self-efficacy in a first year medical course. Advances in Health Sciences Education, 13, 213-232.

Sabzevari, S., Abbaszade, A., \& Borhani, F. (2013). The assessment methods and learning approaches in nursing students of Kerman University of Medical Sciences in Iran. Creative Education, 4(2), 160-164.

Sadlo, G., Richardson, J.T.E. (2003). Approaches to studying and perceptions of the academic environment in students following problem-based and subject-based curricula. Higher Education Research and Development, 22(3), 253-274.

Tiwari, A., Chan, S., Wong, E., Wong, D., Chui, C., Wong, A., \& Patil, N. (2006). The effect of problem-based learning on students' approaches to learning in the context of clinical nursing education. Nurse Education Today, 26, 430-438. 